Mitteilungen der Österreichischen Geographischen Gesellschaft,

158. Jg. (Jahresband), Wien 2016, S. 149-166

\title{
Regional and Gender Differences in Self-employment Motivation: Implications ON Job SuSTaINABILITY
}

\author{
Vera GLIGORIJEVIĆ, Gordana VoJKović, Natalija MiRić, and Petar VAsić, \\ all Belgrade [Beograd]*
}

with 3 tables in the text

\section{CONTENTS}

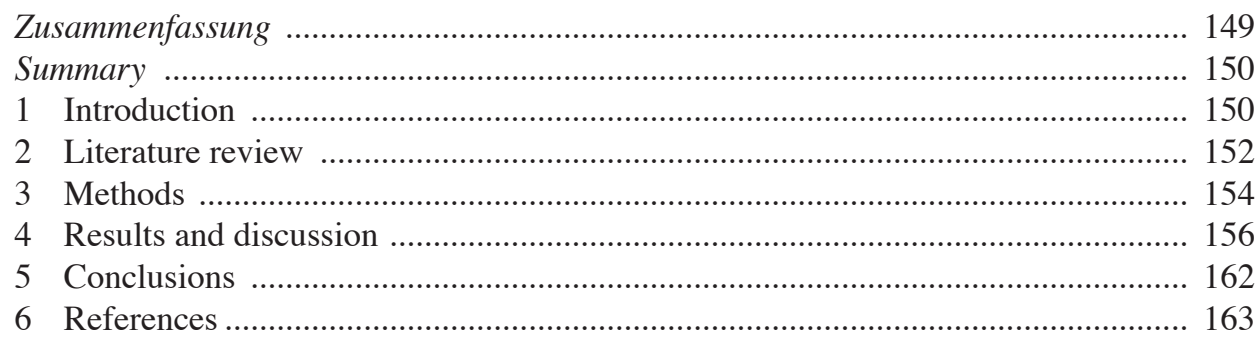

\section{Zusammenfassung}

Regionale und Gender-Unterschiede bei der Motivation zu selbstständiger Erwerbstätigkeit: Folgerungen in Bezug auf nachhaltige Beschäftigung

Ziel dieser Untersuchung war es, regionale und Gender-Unterschiede bei der Motivation zu selbstständiger Erwerbstätigkeit im eigenen Heim in einem ehemals kommunistischen Land (Serbien) herauszufinden. Es ist weithin anerkannt, dass es dabei die Unterscheidung zwischen Unternehmern gibt, die das wegen günstiger Möglichkeiten und solchen, die das aus Notwendigkeit machen, wobei solche Unternehmen die größeren Überlebenschancen haben, die wegen günstiger Möglichkeiten gegründet wurden. Die Tatsache, dass ein großer Teil der befragten Kleinstunternehmer eine günstige Möglichkeit als Motiv der Gründung nannte (56,7\%), lässt vermuten, dass Kleinstunternehmen in Serbien gute Überlebenschancen haben. In die Befragung waren 310 im eigenen Heim selbstständig Erwerbstätige einbezogen (per Post kontaktiert), deren Antworten getrennt

\footnotetext{
* Vera Gligorijević, Assistant professor, Gordana Vojković, Associate professor, Natalija Mirić, Teaching assistant, and Petar VAsIĆ, Teaching assistant, all: University of Belgrade, Faculty of Geography, Department of Demography, Studentski trg 3/3, SR-11000 Beograd, Serbia; email: vera.gligorijevic@gmail.com; gvojkovic@gmail.com; natalymiric@gmail.com; vasic.dem@gmail.com
} 
nach Geschlecht, Lage (städtisch/ländlich) und Art des Wohnorts (Stadt/Dorf) ausgewertet wurden. Auf die Frage nach ihrem vorrangigen Motiv nannten 43,3\% der Befragten „Notwendigkeit“ und bemerkten dazu, dass es ,ihre einzige Möglichkeit Beschäftigung zu finden" sei. Dieses Motiv fand sich häufiger im städtischen als im ländlichen Raum und bei Frauen (48,9\%) als bei Männern (35,8\%). Das weist darauf hin, dass es bis zum Ausgleich des Genderunterschieds noch weit ist und dass darauf am Arbeitsmarkt wie auch in anderen Politikfeldern (z.B. lokale wirtschaftliche Entwicklung) zu achten wäre. Die Ergebnisse könnten dazu beitragen, dass selbstständige Erwerbstätigkeit im eigenen Heim als wichtiger Beitrag zur Nachhaltigkeit ländlicher Gemeinschaften angesehen, bewusst gemacht und auch entsprechend gefördert wird.

Schlagwörter: selbstständige Erwerbstätigkeit, Heimarbeit, ländliche Entwicklung, Serbien

\section{Summary}

The aim of this study was to determine regional and gender differences in motivators for establishing home-based businesses (HBBs) in a former Communist country, Serbia. It is widely accepted that a divide exists between opportunity-driven and necessity-driven entrepreneurs, with HBBs having a greater chance of survival if they are established for opportunity reasons. The fact that a large proportion of $H B B$ owners in the sample reported opportunity motivators (56.7\%) suggests that HBBs have a good chance of success in Serbia. The sample was devised of 310 HBB owners (contacted via a postal survey), stratified by gender, location (urban/rural) and type of residence (city/village). When asked to select their primary motivator, $43.3 \%$ of respondents selected the necessity motivator, stating that an HBB was "the only chance of employment". Necessity motivators were more frequently cited in urban areas, compared to rural areas, and $48.9 \%$ of women and $35.8 \%$ of men started their own business out of necessity. This indicates that there is still a long way to go before gender gaps are closed, as well as that equality must further be promoted in employment and other spheres of public policy (e.g. local economic development). These observations may contribute to establishing home-based business activities as significant contributors to the sustainability of rural communities, as well as to the promotion of awareness and support for self-employment.

Keywords: Self-employment, home-based business, rural development, Serbia

\section{Introduction}

Over the past few decades, we have witnessed a return to self-employment as a strategy for sustainable rural and community-level economic development (Acs 2006; BLANCHflower 2000; Gibson-Graham 1996; Rowe, Haynes \& Stafford 1999). Harvey (2000) suggested economic growth is caused by the flexible organisation of production. Other 
factors, such as the dominance of the free market and the philosophy of private initiative and entrepreneurship (INTERNATIONAL LABOuR OfFice 1990) as well as new customer requirements (HARVEY 2000) also encourage self-employment. Self-employment in transitional economies is rapidly developing; however, it is limited by the short average lifespan of a business (Government of the Republic of Serbia 2013). In Serbia, between 2010 and 2013, more private firms closed down than were newly opened. In 2014, for the first time in five years, the number of new entrepreneurial businesses established was larger than the number of firms removed from the Serbian Business Registry Agency (2015). The Global Entrepreneurship Monitor (GEM) (Bosma \& HARDING 2007) is the most important international research project that has been monitoring the development of entrepreneurship in its early stages since 1999. GEM includes the Total Early-Stage Entrepreneurial Activity Index (TEA), showing the percentage of people whose entrepreneurial activity lasts less than 42 months, and in 2009, Serbia had a moderate level of $4.9 \%$ (MinISTRY OF Economy and Regional Development 2008). A relatively high prevalence of early-stage entrepreneurial activity in Serbia is consistent with the basic GEM results, which indicate that early-stage entrepreneurial activity is high in all low-income countries. Transitional economies often have a high level of unemployment, and populations that have been forced into entrepreneurial activity as a result of various circumstances.

Literature on entrepreneurship contains numerous models and frameworks to analyse the process of starting a business. Recently, one particular classification scheme has become increasingly common (Acs 2006; HAMILTON 2000). Despite previous arguments that the complex motives of entrepreneurs should not be oversimplified (RousE \& DALLENBACH 1999), many contemporary authors have differentiated between entrepreneurs according to whether they are necessity-driven or opportunity-driven (HARDING et al. 2006; MinNITI, Bigrave \& Autio 2006; Smallbone \& Welter 2004). Opportunity-driven entrepreneurs are those who start their businesses in order to pursue a business opportunity, while necessity-driven entrepreneurs are more requirement-based (REYNOLDS et al. 2005). Self-employment as one form of entrepreneurship has been driven by different factors, in both developed and developing countries (BERGLANN et al. 2011). In investigating motives for self-employment, some authors argue that self-employment is predominantly driven by positive factors, especially for the off-farm self-employed (DENNIS 1996; TAYLOR 1996; Salgado-Banda 2005; European Commission 2012).

Regional and gender differences in motivators provide additional understanding of an economy's entrepreneurial profile and facilitate development of adequate regional- and gender-sensitive strategies for local economic development. Given the country-specific context, home-based businesses (HBBs) were selected for three main reasons. Firstly, an HBB does not require large initial investments in facilities, which presents one of the barriers to entrepreneurship in poor transitional economies. Therefore a prevalence of HBBs over other forms of self-employment is to be expected. Secondly, HBBs provide the opportunity to explore the more sophisticated motivators for self-employment, which are a characteristic of new economies and the development of information communication technologies (i.e., the prevalence of flexible work and striving for work-life balance). And finally, the literature suggests that HBBs are the fastest-growing form of micro-business in developed economies (ENTERPRISE NATION 2014; OrgANISATION FOR ECONOMIC Co-OPER- 
ATIOn And Development 2014). Therefore, it is interesting to explore the extent to which they have developed in transitional economies. Additionally, the HBB model is of particular importance for the development of entrepreneurship in rural regions (DwELLY, MAGUIRE \& Truscot 2006; HAnson et al. 2013; MAsOn, CARTER \& TAGG 2011), which cover more than $90 \%$ of the territory and in which $80 \%$ of the population in Serbia resides (GLIGORIJEVIĆ \& DEVEDžıć 2011). Furthermore, the HBB has great significance for the growth of employment among the female population (Loscocco \& Smith-Hunter 2004; Walker \& WeBster 2004; WALKer, WANG \& REDMOND 2008), therefore it may be effective in alleviating unemployment among the female population of Serbia, particularly in rural regions where emigration has created a gender imbalance - the ratio of the male to female population is currently 52:48 (GLIGORIJEVIĆ 2012).

\section{Literature review}

Previous research suggests businesses are more likely to be successful if initiated by individuals motivated by factors such as the desire to be independent, the need for personal achievement (BLAWATT 1998) and experience from previous work (AMMONS \& Markham 2004; Soldressen, Fiorito \& He 1998). In much of the recent literature on entrepreneurial motivation, authors insisted on the differences between necessity-driven motivators (individuals being pushed into entrepreneurship due to lack of a better alternative) and opportunity-driven motivators (individuals wishing to exploit a favourable business opportunity) (Bosma \& Harding 2007; SMAllbone \& Welter 2004). There has been a shift in contemporary entrepreneurship literature towards this dichotomised classification, reflected not only in its use by the GEM, but also in the emerging literature seeking to unravel the meaning of entrepreneurial opportunity (CASSON \& WADESON 2007; COMPANYS \& McMullen 2007; Plummer, Haynieet \& Godesiabois 2007).

There is limited research defining the relationship between the different types of motivation and the lifespan of a business. The reasons behind differences in the lifespan of businesses remain an open question from a theoretical point of view. In this sense, arguments from human capital theory, which suggest that opportunity-driven entrepreneurs remain self-employed for longer than necessity-driven entrepreneurs, may help explain these reasons. Human capital theory (BECKER 1964; SchulTz 1961) maintains that a greater stock of knowledge provides individuals with a higher cognitive ability, which then leads to more productive and efficient activity. Hence, individuals with more knowledge, or with a stock of knowledge of higher quality, are better at perceiving and exploiting entrepreneurial opportunities than entrepreneurs with less human capital (DAVIDSON \& Honig 2003). BLOCK \& SANDNER (2009) argue that opportunity-driven entrepreneurs, who start their ventures voluntarily, have more knowledge and/or knowledge of a higher quality than necessity-driven entrepreneurs. Opportunity-driven entrepreneurs are likely to have prepared more systematically for their entry into self-employment, and are likely to have invested more in the specific human capital necessary to succeed as a business owner. 
Despite motivators for business creation being well established in literature, there is a dearth of research concerning business creation motivators specific to its operating location. This may be because when considering motivators, the HBB has been linked to self-employment and small business, with Thompson, Jones-Evans \& Kwong (2009) reporting for their all-female sample of business owner-operators that motivators are similar irrespective of business location.

One of the principal reasons why people choose to be HBB entrepreneurs is aspiration for independence (Hessels, Gelderen \& Thurik 2008; Paige \& Littrell 2002; JuRiK 1998; CARTER et al. 2003). Another major reason is that HBBs give entrepreneurs flexibility with regard to decision-making, work location, working hours, and leisure and family time (Rotemberg-Shir \& Wennberg 2011; Kuratko, Hornsby \& NAFFziger 1997). Wealth is often reported as the primary extrinsic motivator for establishing HBBs (CARSRUD et al. 2009; CArter et al. 2003; Kuratko, Hornsby \& Naffzinger 1997; Cassar 2007). In addition, the low overhead costs of HBB start-ups motivate people to work from home (ORSER 1991). It follows from the above discussion that the motivators for starting a HBB hinge on interconnected economic, social, psychological, technological and local factors. The most common motivating factors for operating a HBB are to do with choice, power, and lifestyle; therefore, it could be argued that working from home seems to redefine the notion of career, work, and work-life balance.

Researching gender differences is common in studies exploring motivators of entrepreneurship, and GEM surveys (including the GEM special report on women) consistently emphasise that early-stage entrepreneurial activity is gender-sensitive, because of a combination of cultural, societal and economic reasons (Loscocco \& SMiT-HunTer 2004; WALKER \& WEBSTER 2004). Early-stage entrepreneurial activity is dominated by men, but it is more common for women to start a business venture out of necessity (SINGER, AMOROS \& ARREOLA 2014). Croatia stands out with its gender-balanced, but highly necessity-driven level of entrepreneurship, where $46.3 \%$ of men and $47.2 \%$ of women who started businesses did so out of necessity (Singer, Amoros \& Arreola 2014).

In addition to the motivators for starting a business, the geographical location of an HBB has been found to affect business outcomes, such as growth. Furthermore, several studies report that HBBs are more prevalent in rural areas than in urban areas (DwELLY, Maguire \& Truscot 2006; Mason, CARTer \& TAGg 2011). Few studies dealing with motivators for starting businesses in Serbia, especially their impact on business growth, have been published. According to the GEM reports (Ministry of ECONOMY AND Regional Development 2008), in Serbia, $50.6 \%$ of businesses were created by opportuniy entrepreneurs and $49.4 \%$ by necessity-driven entrepreneurs. Financial motivators were the most commonly cited motivators for starting a business, followed by a desire for independence and work flexibility (Ministry of Economy and Regional Development 2008; Centre for Advanced Economic Studies 2014; Bolčić 1994; Bolčić \& Milić 2002; GligoriJević 2012).

There are few data available on (1) the motivators for starting HBBs, (2) regional and gender differences in motivators and (3) the relationship between motivators and business sustainability in Serbia. Bearing in mind the study hypothesis, that the survival of the business is more likely if an entrepreneur is motivated by opportunity rather than necessity, this paper investigates the regional and gender differences in motivators for self-employ- 
ment in a sample of HBB owners. This sample has made the exploration of work-life balance in Serbia possible because HBBs allow for examination of the connection between two often disparate locations (i.e. home and work) (FELstead \& JEwson 2000).

\section{Methods}

Survey respondents were selected among owners of HBBs. The inclusion criteria were formally and informally self-employed people, who have performed any business activity conducted within their home and/or its surrounding facilities (e.g., garage, shed, workshop, studio or backyard) for profit. HBBs ranged from the processing of farm products and the sale of pottery, arts and crafts, to the provision of accommodation, and cleaning, personal services, recreational, and professional services. Additionally, participants had to have established the job themselves, and not be working for an employer. The exclusion criteria included individual farmers whose products were cultivated for the purpose of subsistence.

The study was performed in two phases. The first phase involved randomly selecting people using the telephone registry in Serbia and determining whether they fulfilled the inclusion criteria. Contact addresses were recorded for those who met the criteria and were willing to participate further in the study. The second phase involved administering the postal questionnaire to owners of HBBs. A sample of 310 randomly selected HBBs was stratified according to three characteristics; location, which was defined as distance from the central market, namely Belgrade [Beograd] (central, semi-peripheral or peripheral areas), type of residence (village/city) and gender of business owners. The central area was defined as home businesses located in Belgrade. Belgrade was chosen as the dominant urban core, but a few HBBs from Novi Sad and Niš were included in the urban core sample because of their similar characteristics, particularly for the compiled data on HBBs. Also, due to the overlap of the areas surrounding Belgrade and Novi Sad, some of HBBs that fall within the overlap-area should have been defined as peripheral according to their distance from Belgrade, but they were classified as semi-periphery due to their proximity to Novi Sad. Semi-periphery covered all areas (rural or urban), which were within $50 \mathrm{~km}$ of Belgrade, and periphery included all settlements outside the semi-periphery.

Motivators were explored in two ways; firstly, respondents chose the most important motivator on a list of responses; secondly, they chose three important motivators and were asked to rank them in descending order. Based on respondents' answers, three tables were constructed for subsequent analysis. The first table shows the structure of the primary motivator in each category (gender, location and type of settlement). The second table shows the frequency of all motivators selected by the respondents. The third table shows the structure of the first-ranked motivators for men and women, according to location and type of settlement. Regional differences of motivators for establishing HBBs were determined using the frequency of the highest-ranked motivator in each location. Frequency of other motivators was also determined for each location. Gender differences in motivators were determined using the same method. 


\begin{tabular}{|c|c|c|c|c|c|c|c|c|}
\hline & \multirow[t]{2}{*}{ Total } & \multicolumn{2}{|c|}{ Gender } & \multicolumn{3}{|c|}{ Location } & \multicolumn{2}{|c|}{$\begin{array}{l}\text { Type of } \\
\text { residence }\end{array}$} \\
\hline & & $\sum_{\Sigma}^{\frac{0}{\pi}}$ & 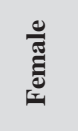 & Ü & 峞 & 它竞 & 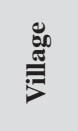 & $\stackrel{\vec{\theta}}{0}$ \\
\hline $\mathrm{N}$ & 310 & 134 & 176 & 46 & 80 & 184 & 200 & 110 \\
\hline P value & & \multicolumn{2}{|c|}{0.91} & \multicolumn{3}{|c|}{0.99} & \multicolumn{2}{|c|}{0.99} \\
\hline \multicolumn{9}{|l|}{ Necessity motivator $(\%)$} \\
\hline Only chance of employment & 43.3 & 35.8 & 48.9 & 58.7 & 45 & 39.6 & 41.5 & 46.4 \\
\hline \multicolumn{9}{|l|}{ Opportunity motivators (\%) } \\
\hline Additional source of income & 17.7 & 14.9 & 19.9 & 08.7 & 15.0 & 21.2 & 19.5 & 14.5 \\
\hline Profitability of business & 13.9 & 17.2 & 11.4 & 15.2 & 22.5 & 09.8 & 14.0 & 13.6 \\
\hline Achievement of ambitions & 09.0 & 10.4 & 08.0 & 08.7 & 08.8 & 09.2 & 06.5 & 13.6 \\
\hline The cost of children's education & 04.2 & 05.2 & 03.4 & - & 01.3 & 06.5 & 05.5 & 01.8 \\
\hline $\begin{array}{l}\text { Knowledgeable/able/educated for } \\
\text { this job }\end{array}$ & 03.9 & 06.0 & 02.3 & 02.2 & 02.5 & 04.9 & 04.5 & 02.7 \\
\hline Hobby and entertainment & 01.9 & 01.5 & 02.3 & - & . & 03.3 & 02.5 & 00.9 \\
\hline Family/inherited business & 01.6 & 03.0 & 00.6 & - & 01.3 & 02.2 & 02.0 & 00.9 \\
\hline Personal use, cost saving & 01.3 & 00.7 & 01.7 & - & 01.3 & 01.6 & 01.5 & 00.9 \\
\hline Technical conditions for business & 00.6 & 01.5 & - & - & - & 01.1 & 01.0 & - \\
\hline Better working conditions & 00.3 & 00.7 & - & 02.2 & - & - & - & 00.9 \\
\hline $\begin{array}{l}\text { Security, required in the market, } \\
\text { the possibility of progress }\end{array}$ & 00.3 & - & 00.6 & 02.2 & - & - & - & 00.9 \\
\hline $\begin{array}{l}\text { Balancing of duties (work-life } \\
\text { balance) }\end{array}$ & 00.6 & 00.7 & 00.6 & - & - & 01.0 & 00.5 & 0.9 \\
\hline $\begin{array}{l}\text { Large investment not required/ } \\
\text { lower costs }\end{array}$ & 00.3 & 00.7 & - & - & 01.3 & - & 00.5 & - \\
\hline Flexibility of working hours & 00.3 & - & 00.6 & 02.2 & - & - & - & 00.9 \\
\hline $\begin{array}{l}\text { Freedom of decision-making } \\
\text { ("own boss") }\end{array}$ & 00.3 & 00.7 & - & - & 01.3 & - & - & 00.9 \\
\hline No answer & 00.3 & 00.7 & - & - & - & 00.5 & 00.5 & - \\
\hline Total & 100 & 100 & 100 & 100 & 100 & 100 & 100 & 100 \\
\hline
\end{tabular}

Note: This table shows the distribution (\% of respondents) of a single primary motivator selected by respondents for starting a home-based business.

Source: Authors, home business survey questionnaire

Tab. 1: Primary motivators for establishing a home-based business in Serbia, by gender, location and type of residence 
Motivators were classified as necessity and opportunity factors, according to previous research and based on country-specific contexts. In the study, the necessity factor was "the only opportunity of employment" - all other motivators were classified as opportunity factors. Statistical analyses were performed using the software package SPSS. Chi-square tests were used to determine differences between potential motivators, stratified by gender, location and type of settlement (Table 1, P value).

\section{Results and discussion}

\subsection{Motivators for self-employment in Serbia}

In this case study of Serbia, several motivators for starting an HBB have been identified. The necessity motivator "only chance of employment", i.e. redundancy, is the primary reason for self-employment for $43.3 \%$ of respondents. Opportunity motivators were cited by $56.7 \%$ of respondents, and the most frequently selected motivators included "additional source of income" (17.7\%), "profitability of business" (13.9\%) and "achievement of ambitions", where $9.0 \%$ of respondents identified this as their primary motivator (Table 1).

If the survival of the business is more likely if an entrepreneur is motivated by opportunity rather than necessity, it could be concluded that $43.3 \%$ of HBBs have little chance for success - their owners may opt for another job as soon as the opportunity arises.

\subsection{Regional differences}

Necessity entrepreneurs were more frequent in central and urban areas, compared with peripheral areas and villages in Serbia. This was unexpected, given the socio-economic transition of the Serbian economy and society. Jobs in the public sector are still the most desirable in Serbia, despite low pay, because they offer regular income, a pension and health insurance. Additionally, the private sector has been developed poorly, for example working conditions are difficult, wages are low and trade unions are marginalised. Therefore, private entrepreneurs are less desirable as employers, in comparison with employers in the public sector. Another employment option is entrepreneurship, which has been poorly developed because of the lack of business training among the labour force and widespread social suspicion towards private property, accompanied by numerous controversies related to non-transparent management. Therefore, it is logical for people to wait for public sector jobs where possible, and these jobs are predominantly located in cities across Serbia, particularly in Belgrade, because of the concentration of government institutions within the city. Furthermore, assessments of employment opportunities are more realistic in villages than cities. The status of being self-employed is more acceptable, and for some people, it is the optimal form of employment, offering the possibility of income and activity diversification. 
Improvement-driven opportunity entrepreneurs are those who have been motivated by the profitability of their business, they make up about half of opportunity-driven respondents. HBBs are often mistakenly viewed as a hobby, and not as a legitimate career choice. The results of the present study show that a significant proportion of respondents make a living from their HBBs; home-based self-employment is not a marginal source of income, it is a serious business that can be relied on.

Self-owned business as an additional source of income has been especially prominent in peripheral areas $(39.6 \%)$ in comparison with central areas $(8.7 \%)$ (Table 1). These results are consistent with findings of Good \& LeVy (1992) and Miller et al. (2003), who contended that generating a profit was the most important reason for operating rural small businesses. They argued that without financial gains, a small business owner could not remain in business for long. Diversifying sources of income has been defined as a motivational factor as well, because of the decline of agricultural productivity and unstable and uncertain earnings in the agricultural sector. Rural areas are more sensitive to fluctuations in the markets of agricultural products, therefore an additional source of income as a motivator is more common in villages and peripheral areas, as opposed to urban areas $-19.5 \%$ of respondents in villages selected this as their primary motivator, while only $14.5 \%$ did so in cities (Table 1).

The profitability of a business as a motivator is the factor most directly associated with longer survival and expansion of business activities, and has been the most frequently identified motivator by respondents in semi-peripheral areas. The peri-urban zones of the capital city have generated the largest proportion of rural-urban migrants, internally displaced people and refugees from former Yugoslav republics, in the last three decades. Profit as key motivator for starting a business was cited by $22.0 \%$ of respondents from semi-periphery, $15.0 \%$ of respondents from city and $9.0 \%$ of respondents from periphery areas. The latter two population categories have emerged as an inevitable consequence of the civil war in the former Yugoslavia during the 1990s. Today, because of migration of the working age population to cities, e.g. Belgrade, the semi-peripheral zone has been inhabited by a relatively young population who use the proceeds from the sale of property in their home countries for starting their own businesses.

Wealth has been identified as a motivator for self-employment in households with children (GLIGORIJEvić 2012), and it has been associated with the high costs of education, especially university education. In the present study, 15.0\% of HBB owners who lived in villages, cited money for children's education as a motivator for self-employment, while none of the urban respondents did (Table 2). The main reason for the large rural-urban differences in the distribution of this motivator could be attributed to the centralisation of higher education in Belgrade and other major cities across Serbia (i.e., the high cost of tuition and accommodation).

Achievement of ambitions was identified as the fourth most common motivator for starting a business in Serbia, with $10.0 \%$ of respondents selecting this as their primary motivator (Table 1). These findings support the theory that factors such as desire and willingness to be independent and successful in both non-monetary and monetary terms, and satisfaction gained from personal achievement by utilising one's own ideas and talents, are the principal motivators for entrepreneurs (FELSTEAD \& JEWSON 2000). 


\begin{tabular}{|c|c|c|c|c|c|c|c|c|}
\hline & \multirow[t]{2}{*}{ Total } & \multicolumn{2}{|c|}{ Gender } & \multicolumn{3}{|c|}{ Location } & \multicolumn{2}{|c|}{$\begin{array}{l}\text { Type of } \\
\text { residence }\end{array}$} \\
\hline & & $\sum_{\Sigma}^{\frac{\varrho}{\pi}}$ & 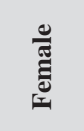 & 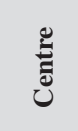 & 完离 & 事 & 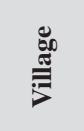 & $\stackrel{3}{0}$ \\
\hline $\mathrm{N}$ & 310 & 134 & 176 & 46 & 80 & 184 & 200 & 110 \\
\hline Only chance of employment & 32.9 & 26.1 & 38.1 & 41.3 & 32.5 & 31.0 & 30.5 & 37.3 \\
\hline Achievement of ambitions & 30.6 & 30.6 & 30.7 & 28.3 & 33.8 & 29.9 & 28.5 & 34.5 \\
\hline Profitability of business & 21.9 & 28.4 & 17.0 & 23.9 & 28.7 & 18.5 & 20.0 & 25.5 \\
\hline Additional source of income & 21.3 & 17.2 & 24.4 & 10.9 & 17.5 & 25.5 & 23.5 & 17.3 \\
\hline Flexibility of working hours & 15.2 & 17.9 & 13.1 & 21.7 & 22.5 & 10.3 & 14.0 & 17.3 \\
\hline $\begin{array}{l}\text { Balancing of duties (work-life } \\
\text { balance) }\end{array}$ & 14.8 & 15.7 & 14.2 & 19.5 & 05.1 & 18.0 & 14.5 & 15.5 \\
\hline The costs of children's education & 10.6 & 11.9 & 09.7 & 04.3 & 06.3 & 14.1 & 15.0 & 00.0 \\
\hline Technical conditions for business & 08.7 & 11.2 & 06.8 & 04.3 & 12.5 & 08.2 & 11.5 & 03.6 \\
\hline $\begin{array}{l}\text { Knowledgeable/able/educated for } \\
\text { this job }\end{array}$ & 08.1 & 12.7 & 04.5 & 08.7 & 03.8 & 09.8 & 08.0 & 08.2 \\
\hline Hobby and entertainment & 07.7 & 04.5 & 10.2 & 04.3 & 07.5 & 08.7 & 07.5 & 08.2 \\
\hline Personal use, cost saving & 04.8 & 01.5 & 07.4 & 02.2 & 01.3 & 07.1 & 05.0 & 04.5 \\
\hline Better working conditions & 03.9 & 04.5 & 03.4 & 02.2 & 07.5 & 02.7 & 03.0 & 05.5 \\
\hline Family/inherited business & 03.2 & 05.2 & 01.7 & 02.2 & 01.3 & 04.3 & 03.0 & 03.6 \\
\hline $\begin{array}{l}\text { Freedom of decision-making } \\
\text { ("own boss") }\end{array}$ & 02.9 & 06.0 & 00.6 & 02.2 & 03.8 & 02.7 & 01.5 & 05.5 \\
\hline Reduce transportation costs & 02.6 & 02.2 & 02.8 & 02.2 & 02.5 & 02.7 & 02.0 & 03.6 \\
\hline $\begin{array}{l}\text { Security, required in the market, } \\
\text { the possibility of progress }\end{array}$ & 02.3 & 01.5 & 02.8 & 02.2 & 03.8 & 01.6 & 02.5 & 01.8 \\
\hline $\begin{array}{l}\text { Large investment not required/ } \\
\text { lower costs }\end{array}$ & 01.9 & 02.2 & 01.7 & 04.3 & 02.5 & 01.1 & 02.5 & 00.9 \\
\hline No answer & 00.3 & 00.7 & - & - & - & 00.5 & 00.5 & - \\
\hline
\end{tabular}

Note: This table shows the frequency distribution of motivational factors based on multiple responses. Respondents were asked to select three motivators. Data represent the percentage of respondents for each motivator.

Tab. 2: All motivators for starting a home-based business. Multiple responses by location, gender and type of residence

The proportion of respondents who stated "achievement of ambitions" as one of the three main motivators amounted to $30.0 \%$ (Table 2). Since the proportion of two very important opportunity motivators, ambition pursuit and earnings, is high, almost half of 
all respondents should have a good chance of keeping their jobs. Even with emergence of new jobs in the public and private sectors (although unlikely in the next decade), the vast majority of respondents who have fulfilled their ambitions by establishing an HBB may not want to pursue corporate careers in place of owning a business.

Motivators such as work-life balance, flexible working hours, and freedom of decision-making ("being your own boss") have rarely been the first reason for self-employment in Serbia (from 0.3 to $0.6 \%$, Table 1), in contrast with developed countries (Dwelly, Maguire \& Truscot 2006; Enterprise Nation 2014; Loscocco \& Smith-Hunter 2004; MASON, CARTER \& TAGG 2011). In developed countries, HBB is a flexible form of work and a frequent choice for employees, even if they are earning less (OAKLEY 2007), because it reduces stressful situations for working parents and is an especially attractive option for working mothers, "mompreneurs" (EKInSMYth 2011; Baines \& Gelder 2003; MASON, CARTER \& TAGG 2011). There are two main reasons for the absence of these motivators in Serbia. Firstly, financial motivators for self-employment have been dominant in Serbia, where poverty is widespread: The prevalence of those at risk of poverty was $24.6 \%$ in 2012 (Statistical Office of Republic of Serbia 2015). Secondly, work-life balance in Serbia has been facilitated by state-provided childcare. This system was established during the Socialist period, when female economic activity was unimodal (i.e., mothers did not withdraw from the labour market to raise children) (WERTHEIMER-BALETIĆ 1999). Although this service is still available to all mothers, the care provided is considered to be of poor quality (Matкović \& Misatović 2009). Free compulsory primary education provides continuity of social care for children, thereby helping mothers remain in the labour force.

As expected, work-life balance was a little more important to respondents from peripheral areas, compared to respondents from central areas (Table 1). This could be explained by employed persons having difficulties in balancing childcare and work duties because of a lack of kindergartens and pre-school institutions in rural areas. Additionally, the number of elderly people needing daily care has been increasing in peripheral areas because of population aging; communities in Serbian villages are older than those in cities. Furthermore, there are more intergenerational families in villages; grandparents, parents and children sharing a household. Care for the elderly is usually provided by employed adults. For these people, HBB is a good option because it enables individuals to take care of elderly family members and work at the same time.

However, looking at the frequency distribution of motivational factors based on multiple responses (not only the primary motivator), work-life balance was not an equally important motivator for all respondents in this study (Table 2). It is interesting that only $5.0 \%$ of respondents from semi-peripheral areas considered work-life balance an important motivator for starting a business (average value for all respondents is $15.2 \%$, Table 2). This could be explained by the structure of families in the semi-peripheral areas of Belgrade, where multigenerational families are common (GLIGORIJEvić 2012). These families migrated from inside former Yugoslavia, where intergenerational living is a deeply rooted tradition. It is common that grandparents are responsible for childcare and that younger members of the family care for their grandparents.

The Chi Square test (X2) was used to analyse the significant motivators' difference in central, semi-peripheral and peripheral regions and villages and cities (Table 1, Row 4). 
Since the p-value in both cases equals 0.99 , we have concluded that the differences between HBB samples from the urban core and fringe regions are statistically insignificant at a 0.95 significance level.

\subsection{Gender differences}

In this study, necessity motivators were not equally divided between male and female respondents; $48.9 \%$ of women were self-employed out of necessity compared to $35.8 \%$ of men (Table 1). This difference may have been a consequence of the limited employment opportunities available to Serbia's increasing labour force of educated women. Unemployment among women, especially long-term unemployment, has remained high despite the formal labour market offering more jobs for women, including trade, education, health, public administration and financial services. Increasing job opportunities for women are a result of structural changes in the Serbian economy and the transition towards a more prominent service sector, which has led to higher employment levels, although unemployment still persists in the female population. The smaller number of men classified as necessity entrepreneurs could be explained because of the superior position of men in the labour market in Serbia. However, there were men who were self-employed out of necessity $(35.8 \%)$, and this indicates men also face difficulties in the labour market.

Opportunity motivators were more frequent in men than in women. Over $64 \%$ of men and over $50 \%$ of women were motivated by some of the opportunity factors. Profit was unequally important for men and women, with $17.2 \%$ of men and $11 \%$ of women selecting these motivators. The motivator "profitability of the business" was more frequent in men, as well as other opportunity motivators such as "achievement of ambitions", "being your own boss" and "knowledgeable/able/educated for job" or the desire to continue the family business, all of which were rare among women (Table 1). The "additional source of income" motivator was noticeably more frequent in women, than in men. This could be related to the nature of $\mathrm{HBBs}$, because $\mathrm{HBBs}$ more frequently represent an additional source of income for women, than in men (Statistical Office of Republic of Serbia 2014). Given that a fifth of women have a job in addition to an HBB, another concern was how to balance a home business and employment outside the home (Statistical Office of Republic of Serbia 2014). Not only do HBBs have to fit in with other jobs outside the home, they must also fit in unpaid housework. Data published by the Statistical OfFice of the Republic of SERBIA (2014) shows the mean time spent on unpaid housework is 2 hours 17 minutes for men, compared with 4 hours and 51 minutes for women. This means the maintenance of the household often requires interruption of paid work, even in families without children.

Motivators related to family goals, including being close to the family, were almost equally important for women and men. The presence of these motivators in HBB owners is evident from the frequency of respondents who selected flexible working hours and balancing duties as motivators (Table 1).

The frequency distribution of motivational factors based on multiple responses (Table 2) indicate that the most frequently selected motivators are those associated with earnings (only chance of employment, additional source of income and profit), with nearly $80.0 \%$ 
of men and $85.0 \%$ of women selecting these motivators. An equal proportion of men and women $(30.0 \%)$ selected "achievement of ambitions" as a motivator. A high proportion of men selected motivators associated with family, including work-life balance $(15.7 \%)$, flexibility of working hours $(18.0 \%)$ and better working conditions (4.5\%). This suggests a greater homogeneity of motivators between men and women when multiple motivators are taken into account, rather than a single primary motivator. Additionally, multiple responses did not account for the gender differences in motivators such as "profit" and "knowledgeable/able/educated for this job", which were dominant in male respondents or in the motivators such as "own boss" and "hobby and entertainment", which were more frequent in women.

Motivators associated with earnings were the most important for men and women from all areas (Table 3), especially for women from semi-peripheral areas (93.3\%). Non-economic motivators were more frequent in men than in women, especially in men who lived in cities, where almost $40.0 \%$ of men established an HBB out of non-economic reasons (mainly "achievement of ambitions", "own boss" and "balance of duties"). Data on non-economic motivators are important in the context of sustainable development, because previous research suggests that the survival and development of a business is significantly affected by non-economic factors (Harding et al. 2006; Minniti, Bygrave \& Autio 2006; Perunović 2005), especially in terms of the new economy (HARVEY 2000; WALKER, WANG \& REDMOND 2008). Therefore, it can be argued that the chance of sustainable development of HBBs is the highest for men who live in cities and lowest for women in the semi-peripheral areas in Serbia. HBBs in semi-peripheral areas have the most homogeneous structure of motivational factors and therefore the least chance of survival. Interestingly, for this area, motivators such as work-life balance were not considered important by respondents. It appears that entrepreneurs from semi-peripheral areas were solely motivated by economic reasons.

HBBs in peripheral and rural settlements in Serbia have the most heterogeneous structure of motivational factors and therefore the greatest chance of survival and development, including many non-economic motivators, as well as economic motivators (achievement of ambitions, work-life balance, own boss, hobby and entertainment, previous work experience, the continuation of family business, etc.). These results are consistent with attitudes that HBBs are vital components of rural entrepreneurship (DwELLY, MAGUiRE $\&$ TRuscot 2006), and the sustainability of rural households and communities (Rowe, HAYNER \& STAFFORD 1999). HBBs contribute to household income, and generate employment opportunities and wealth in communities. Additionally, they offer opportunities for income diversification in rural agricultural households.

Judging by the share of non-economic motivators for self-employment (most frequent1y; "achievement of ambitions", "work-life balance" and "previous work experience"), the greatest chances of survival of women's businesses are in the urban areas and in the centre of Belgrade, rather than in villages and peripheral areas. This could be associated with the structure of female entrepreneurship in Serbia, which is different between Belgrade and other regions; female entrepreneurs outside Belgrade are more likely to start a business in the industrial sector and to further enlarge a business in the trade sector, while women in Belgrade are more likely to start a business within the information technology, consulting, and finance sectors (SERBIAN Association of EMPloyers 2013). 


\begin{tabular}{|c|c|c|c|c|c|c|c|c|c|c|}
\hline & \multicolumn{5}{|c|}{ Male } & \multicolumn{5}{|c|}{ Female } \\
\hline & U் & 离离 & & 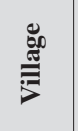 & $\stackrel{\Xi}{\sharp}$ & Uूँ & ڤั. & & 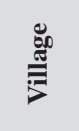 & 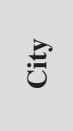 \\
\hline $\begin{array}{l}\text { Motivators associated } \\
\text { with earnings }\end{array}$ & 70.0 & 78.5 & 63 & 75 & 60.7 & 80.7 & 93.3 & 79.7 & 83.7 & 81.8 \\
\hline $\begin{array}{l}\text { Achievement of } \\
\text { ambitions }\end{array}$ & 10.0 & 14.3 & 10.8 & 7.1 & 21.4 & 11.5 & 6.6 & 7.5 & 6.2 & 9.1 \\
\hline $\begin{array}{l}\text { Previously work } \\
\text { experience }\end{array}$ & 10.0 & - & 6.5 & 5.3 & - & - & - & 2.5 & 1.2 & 1.8 \\
\hline Balance of duties & - & - & 4.3 & 1.7 & 7.1 & 7.6 & - & 1.2 & - & 3.6 \\
\hline $\begin{array}{l}\text { Freedom of decision- } \\
\text { making ("own boss") }\end{array}$ & - & 7.1 & - & - & 10.7 & - & - & - & - & - \\
\hline $\begin{array}{l}\text { The costs of children's } \\
\text { education }\end{array}$ & - & - & 10.8 & 7.1 & - & - & - & 2.5 & 2.5 & - \\
\hline Hobby and entertainment & - & - & - & 1.7 & - & - & - & 5.1 & 5 & - \\
\hline $\begin{array}{l}\text { Family/inherited } \\
\text { business }\end{array}$ & - & - & 4.3 & - & - & - & - & - & - & - \\
\hline $\begin{array}{l}\text { Better working } \\
\text { conditions }\end{array}$ & 10.0 & - & - & - & - & - & - & - & - & - \\
\hline Other & - & - & - & 1.7 & - & - & - & 1.2 & 1.2 & 3.6 \\
\hline Total \% & 100 & 100 & 100 & 100 & 100 & 100 & 100 & 100 & 100 & 100 \\
\hline
\end{tabular}

Note: This table presents an extract of motivators. More precisely, the table presents the percentage of participants who chose each primary motivator for starting home-based businesses in men and women in the centre, semi-periphery, and periphery locations, and villages and cities in Serbia. All motivation factors of a financial nature are classified as economic reasons.

Tab. 3: Differences in motivators for establishing home-based businesses in Serbia, by gender, location and type of residence

\section{Conclusions}

In the last 25 years, self-employment in Serbia has been encouraged by public policy. The main objective of these policies is to reduce the level of unemployment and increase individual and household income, consequently improving the standard of living and contributing to sustainable development of communities. Therefore, great importance is placed on each newly established HBB. The problem is that the average age of these businesses is short.

Based on the GEM conceptual framework introduced to differentiate between necessity-driven and opportunity-driven entrepreneurial activity, the results from this study sug- 
gest that HBBs have a good chance of survival in Serbia. The results presented in this paper indicate that different factors shaping the sustainability of businesses are not mutually exclusive: A combination of factors such as geographical location and the characteristics of the businesses and its managers, particularly the gender of managers, influence the sustainability of the business. Regardless of geographic areas, the motivator of increasing household income was key for setting up HBBs. However, there were geographically distinct differences in other motivational factors. HBB owners surveyed in urban areas were more likely to become self-employed because of flexible working and using previous work experience, compared with HBB owners in peri-urban and peripheral areas.

Gender differences were also exposed: non-economic reasons such as independence, flexibility, job satisfaction, family considerations and accessibility have contributed largely to the growth and survival of female-owned businesses. Working from home, while raising children and choosing a job closer to home strengthens family bonds, which is an important element in the sustainability of households and communities. It is worth stressing here that this does not mean financial considerations were less important for female HBB owners. Another reason for the growing interest of women in HBBs may be the low financial requirements and minimal initial training required to establish these businesses. Therefore, for most of these female entrepreneurs, HBBs are more of a lifestyle choice. The implication is that the revitalisation and sustainability, especially of rural areas and small communities, must come from entrepreneurial initiatives.

Working from home is not only satisfying but challenging (BERKE 2003; HECK, WALKER \& FURRY 1995). Problems, which can arise are more common in peripheral and rural areas because of isolation, lack of face-to-face contact and limitations in terms of facilities. Several challenges undermined the potential and sustainability of HBBs. The two most significant ones are financial constraints and public perception and attitudes towards HBBs. HЕск et al. (1995) argued that the trend toward home-based work has undergone a quiet revolution; hence, little attention has been given to the significant role HBB plays in sustainable community development. HBBs represent a legitimate lifestyle and career choice for the individuals and households who operate them. This form of business activity is not a 'marriage of convenience' or just a 'female occupation'. Failure to recognise this form of occupation as part of the economy is tantamount to the loss of a significant alternative strategy and opportunity for sustainable community development.

\section{References}

Acs Z.J. (2006). How is Entrepreneurship Good for Economic Growth? In: Innovations: Technology, Governance, Globalization, 1, 1, pp. 97-107.

Ammons S.K., Markham W.T. (2004), Working at home: Experiences of skilled white collar workers. In: Sociological Spectrum, 24, 2, pp. 191-238.

BAINES S., GELDER U. (2003), What is family friendly about the workplace in the home? The case of self-employed parents and their children. In: New Technology, Work and Employment, 18, 3, pp. 223-234. 
BeCKer G. (1964), Human Capital. Chicago, University of Chicago Press.

Berglann H., Moen E., Røed K., Skogstrøm J.F. (2011), Entrepreneurship: Origins and returns. In: Labour Economics, 18, 2, pp. 180-193.

Berke D.R. (2003), Coming home again: The challenges and rewards of home-based self-employment. In: Journal of Family Issues, 24, 4, pp. 513-546.

BlanchFlower D.G. (2000), Self-employment in OECD countries. In: Labour Economics, 7, 5, pp. 471-505.

BlawatT K.R. (1998), Entrepreneurship: Process and Management. Toronto, Prentice Hall.

Block J., Sandner P. (2009), Necessity and Opportunity Entrepreneurs and their Duration in Self-employment: Evidence from German Micro Data. In: Journal of Industry, Competition and Trade, 9, 2, pp. 117-337.

BoLČIĆ S. (1994), Problems of the transition to an entrepreneurial society. Belgrade, Institute for Sociological Research, Faculty of Philosophy.

Bolčlć S., Milić A. (2002), Serbia at the end of the millennium: the destruction of society, changes and everyday life. Belgrade, Institute for Sociological Research, Faculty of Philosophy.

Bosma N, Harding R. (2007), Global Entrepreneurship Monitor: GEM 2006 Results. London, London Business School.

CAsson M., Wadeson N. (2007), The Discovery of Opportunities: Extending the Economic Theory of the Entrepreneur. In: Small Business Economics, 28, 4, pp. 285-300.

Carsrud A., Brännback M., Elfving J., Brandt K. (2009), Motivations: The Entrepreneurial Mind and Behavior. In: CARSRUd A., BRÄNNBACK M. (eds.), Understanding the Entrepreneurial Mind. New York, Springer.

Carter N.M., Gartner W.B., Shaver K.G., Gatewood E.J. (2003), The career reasons of nascent entrepreneurs. In: Journal of Business Venturing, 18, 1, pp. 13-39.

CASSAR G. (2007), Money, money, money? A longitudinal investigation of entrepreneur career reasons, growth preferences and achieved growth. In: Entrepreneurship \& Regional Development, 19, 1, pp. 89-107.

Centre for Advanced Economic Studies (ed.) (2014), Entrepreneurship in Serbia - necessity or opportunity? Belgrade, CEVES.

Companys Y., McMullen J. (2007), Strategic entrepreneurs at work: the nature, discovery and exploitation of entrepreneurial opportunities. In: Small Business Economics, 28, 4, pp. 301-322.

Davidson P., Honig B. (2003), The Role of Social and Human Capital among Nascent Entrepreneurs. In: Journal of Business Venturing, 18, 3, pp. 301-331.

DenNIS J. (1996), Self-employment: When nothing else is available? In: Journal of Labour Research, 17, 4, pp. 645-661.

Dwelly T., Maguire K., Truscot F. (2006), Under the Radar: Tracking and supporting rural homebased business. Chelenham, Live Work Network and Commission for Rural Communities.

EUROPEAN COMMISSION (ed.) (2012), Self-employment and entrepreneurship: the contribution of PES to job creation, Employment, Social Affairs \& Inclusion. - http://www.mobilitypartnership. eu/webapp/Events.aspx? EventID=21 (Accessed July $7^{\text {th }}, 2014$ ).

EкinsmYth C. (2011), Challenging the boundaries of entrepreneurship: The spatialities and practices of UK 'Mumpreneurs'. In: Geoforum, 42, 1, pp. 104-114.

ENTERPRISE NATION (ed.) (2014), Home Business Report. - https://www.enterprisenation.com/homebusiness (Accessed January 12 $2^{\text {th }}, 2015$ ).

Felstead A., Jewson N. (2000), Work at Home: Towards an Understanding of Homeworking. London, Routledge.

Gibson-Graham J.K. (1996), The End of Capitalism (as we knew it): A Feminist Critique of Political Economy. Oxford (UK), Blackwell Publishes Inc. 
GligoriJević V. (2012), Economic-geographical and demographic changes of the agrarian area in Serbia. Doctoral thesis, University of Belgrade, Faculty of Geography.

Gligorijević V., Devedžıć M. (2011), Changes in the distribution of the rural population in Serbia. In: Collection of Papers - Faculty of geography at the University of Belgrade, 59, pp. 1-14.

Good W.S., Levy M. (1992), Home-Based Business: A phenomenon of Growing Economic Importance. In: Journal of Small Business and Entrepreneurship, 10, pp. 34-46.

Government of the Republic of Serbia (ed.) (2013), Report on development of Serbia 2012. Belgrade, Ministry of Regional Development and Local Government.

Hamilton B. (2000), Does entrepreneurship pay? An empirical analysis of the returns to selfemployment. In: Journal of Political Economy, 108, 3, pp. 604-628.

Hansson H., Ferguson R., Olofsson C., Rantomäki-Lahtinen L. (2013), Farmers' motives for diversifying their farm business: The influence of family. In: Journal of Rural Studies, 32, pp. 240-250.

Harding R., Brooksbank D., Hart M., Jones-Evans D., Levie J., O’Reilly M., Walker J. (2006), Global Entrepreneurship Monitor United Kingdom 2005. London, Business School.

Harvey D. (2000), Time-space compression and postmodern condition. In: Held D., McGrew A. (eds.), The Global Transitions Reader: An Introduction to the Globalization Debate, pp. 82-91. Cambridge, UK, Polity Press.

Heck R.K.Z., Walker R., Furry M. (1995), The workers at work at home. In: Heck R.K.Z., Owen A.J., Rowe B.R. (eds.), Home-Based Employment and Family, pp. 41-74. Westport (CT), Auburn House.

Hessels J., Gelderen M., Thurik R. (2008), Entrepreneurial aspirations, motivations, and their drivers. In: Small Business Economics, 31, 3, pp. 323-339.

International Labour Office (ed.) (1990), The Promotion of Self-Employment Report VII: International Labour Conference $77^{\text {th }}$ Session. Geneva, ILO Publication.

JURIK N.C. (1998), Getting Away and Getting By. In: Work and Occupations, 25, 1, pp. 7-35.

Kuratko D.F., Hornsby J.S., NAFFZiger D.W. (1997), An Examination of Owner's Goals in Sustaining Entrepreneurship. In: Journal of Small Business Management, 35, 1, pp. $24-33$.

Loscocco K., Smit-Hunter A. (2004), Women home-based business owners: Insights from comparative analyses. In: Women in Management Review, 19, 3, pp. 164-173.

MASON C.M., CARTER S., TAGG S. (2011), Invisible Businesses: The Characteristics of Home-based Businesses in the United Kingdom. In: Regional Studies, 45, 5, pp. 625-639.

Matković G., Misatović B. (2009), Analysis of the State's Financial Support to The Poor. DPM's Poverty Reduction Strategy Implementation Focal Point. Belgrade, Official Herald.

Miller N.J., Besser T.L., GASkill L.R., SAPP S.G. (2003), Community and managerial predictors of performance in small rural US retail and services firms. In: Journal of Retailing and Consumer Services, 10, pp. 215-230.

Ministry of Economy and Regional Development (ed.) (2008), Report on small and medium-sized enterprises and entrepreneurship (SMEE Report). Belgrade, Ministry of Economy and Regional Development of the Republic of Serbia, Republican Agency for Development of SME and Entrepreneurship.

Minniti M., Bygrave W., Autio E. (2006), Global Entrepreneurship Monitor: 2005 Executive Report. London, Business School.

OAKLEY D. (2007), Remote traders are at home with growing trend. In: Financial Times, 25 May, p. 3.

Organisation for Economic Co-operation and Development (OECD) (ed.) (2014), Entrepreneurship at a Glance 2014. Paris, OECD Publishing.

ORSER B.J. (1991), Methodological and theoretical issues of research in home-based business. In: Journal of Small Business and Entrepreneurship, 8, 2, pp. 21-38. 
Paige R.C., Littrell M.A. (2002), Craft retailers criteria for success and associated business strategies. In: Journal of Small Business Management, 40, 4, pp. 314-331.

Perunović Z. (2005), Introducing Opportunity-Based Entrepreneurship in a Transition Economy. Michigan, William Davidson Institute, University of Michigan.

Plummer L.A., Haynie J.M., Godesiabois J. (2007), An essay on the origins of entrepreneurial opportunity. In: Small Business Economics, 28, 4, pp. 363-379.

Reynolds P.D., Bosma N., Autio E., Hunt S., De Bono N., Servais I., Lopez-Garcia P., Chins N. (2005), Global Entrepreneurship Monitor: Data Collection Design and Implementation 1998-2003. In: Small Business Economics, 24, 3, pp. 205--231.

Rotemberg-Shir N., Wennberg K. (2011), A Contingency model of Entrepreneurial Entry Strategies: The role of Motivation and Resource Availability. - http://www.icsb2011 .org/downloa $d / 18.62$ efe22412f41132d41800012762/173.pdf (Accessed July $7^{\text {th }}, 2012$ ).

Rouse M., Dallenbach U. (1999), Rethinking research methods for the resource-based perspective: isolating sources of sustainable competitive advantage. In: Strategic Management Journal, 20, 5, pp. 487-494.

Rowe B.R., HAYNES G.W., STAFFoRd K. (1999), The contribution of home-based business income to rural and urban economies. In: Economic Development Quarterly, 13, 1, pp. 66-77.

Salgado-BAnda H. (2005), Entrepreneurship and Economic Growth: An Empirical Analysis (= DEGIT Conference Papers from Digit, Dynamics, Economic Growth and International Trade), Geneva, Graduate Institute Geneva.

Schultz T.W. (1961), Investment in Human Capital. In: American Economic Review, 51, 1, pp. 1-17.

Serbian Business Registry Agency (ed.) (2015), News. Aggregate annual data from the Register of firms. - http://www.apr.gov.rs (Accessed January 15th 2015 ).

Serbian Association of Employers (ed.) (2013), Evaluation environment for women entrepreneurship in Serbia. Belgrade, Serbian Association of Employers.

Singer S., Amoros J.E., Arreola D.M. (2014), Global Entrepreneurship Monitor 2014 Global Report. London, Global Entrepreneurship Research Association (GERA).

Smallbone D., Welter F. (2004), Entrepreneurship in Transition Economies: Necessity- or Opportunity-Driven? Paper presented at the Babson-Kauffman Entrepreneurship Research Conference (BEKERC), Babson College.

SoldResSEn L.S., Fiorito S.S., HE Y. (1998), An exploration into home-based businesses: Data from textile artists. In: Journal of Small Business Management, 36, 2, pp. 33-44.

Statistical Office of the Republic of Serbia (ed.) (2014), How three generations use their time in the Republic of Serbia 2010/11. Belgrade.

Statistical Office of the Republic of Serbia (ed.) (2015), Survey of income and living conditions SILC. Belgrade.

TAYLOR M. (1996), Earnings, independence or unemployment: why become self-employed? In: Oxford Bulletin of Economics and Statistics, 58, 2, pp. 253-266.

Thompson P., Jones-Evans D., Kwong C. (2009), Women and Home-based Entrepreneurship: Evidence from the United Kingdom. In: International Small Business Journal, 27, 2, pp. 227 239.

Walker E., Webster B. (2004), Gender issues in home-based businesses. In: Women in Management Review, 19, 8, pp. 404-412.

Walker E., WANG C., Redmond J. (2008), Women and work-life balance: is home-based business ownership the solution? In: Equal Opportunities International, 27, 3, pp. 258-275.

Wertheimer-Baletić A. (1999), Population and Development. Zagreb, MATE. 